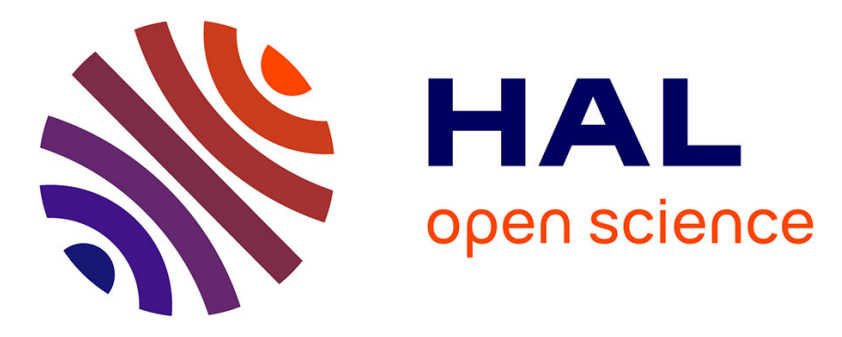

\title{
Understanding transition in animal based food consumption: a case study in the city of Vadodara in Gujarat (India)
}

Estelle Fourat, Shagufa Kapadia, Urvi Shah, Vaishali Zararia, Nicolas Bricas

\section{- To cite this version:}

Estelle Fourat, Shagufa Kapadia, Urvi Shah, Vaishali Zararia, Nicolas Bricas. Understanding transition in animal based food consumption: a case study in the city of Vadodara in Gujarat (India). Review of Agricultural, Food and Environmental Studies, 2018, 99 (2), pp.189-205. 10.1007/s41130018-0076-7 . hal-03114753

\section{HAL Id: hal-03114753 \\ https://hal.science/hal-03114753}

Submitted on 19 Jan 2021

HAL is a multi-disciplinary open access archive for the deposit and dissemination of scientific research documents, whether they are published or not. The documents may come from teaching and research institutions in France or abroad, or from public or private research centers.
L'archive ouverte pluridisciplinaire $\mathbf{H A L}$, est destinée au dépôt et à la diffusion de documents scientifiques de niveau recherche, publiés ou non, émanant des établissements d'enseignement et de recherche français ou étrangers, des laboratoires publics ou privés. 


\title{
Understanding transition in animal based food consumption: a case study in the city of Vadodara in Gujarat (India)
}

\author{
Estelle Fourat $^{1}$ • Shagufa Kapadia ${ }^{2}$ - Urvi Shah ${ }^{3}$. \\ Vaishali Zararia $^{4} \cdot$ Nicolas Bricas $^{5,6}$
}

\begin{abstract}
India is experiencing a modernisation process characterised by rapid urbanisation and the emergence of a new middle class. This process is expected to lead to a change in lifestyles and dietary patterns, and notably higher consumption of animal based foods. The present article focuses on this changing dietary trend in the city of Vadodara in Gujarat (India). A stratified sample of 432 women and men was selected, representing Brahmin, non-Brahmin and Jain communities from high, medium and low socioeconomic strata. The results revealed that, in the transition process, the supposed protein shift from plant- to animal based foods takes specific forms in this cultural context because of more complex drivers that shape food consumption than the socioeconomic position in the society. It highlights that beyond the supra-determination of castes and socioeconomic classes, major drivers of this consumption are the norms and values attached to foods and their interrelations with eating practices according to spatiotemporal and social dimensions. This Indian case reveals that dietary change is not unidirectional towards the Western model but each culture has a unique form of transition.
\end{abstract}

Estelle Fourat

efourat@gmail.com

1 Université Libre de Bruxelles, Avenue Jeanne, 44, B-1050 Bruxelles, Belgium

2 Department of Human Development and Family Studies, and Women's Studies Research Center, Faculty of Family and Community Sciences, The M.S. University of Baroda, Gujarat, India

3 Population Research Centre, Faculty of Science, The M.S. University of Baroda, Gujarat, India

4 Women's Studies Research Center, Faculty of Family and Community Sciences, The M.S. University of Baroda, Gujarat, India

5 CIRAD, UMR MOISA, F-34398 Montpellier, France

6 MOISA, Université Montpellier, Montpellier, France 
Keywords Nutrition transition - Animal based foods $\cdot$ Diet categories $\cdot$ Vegetarian/Non vegetarian $\cdot$ India $\cdot$ Eating practices

\section{Introduction}

The increasing worldwide consumption of animal based food is having significant environmental, economic, social, ethical and health impacts (Steinfeld et al. 2006; Esnouf et al. 2011). Many authors support the idea of a universal transition whereby dietary shifts follow a linear process from a 'traditional' plant-based diet to a 'modern' diet high in animal based foods, with culture moderating or accelerating the speed of the shift (Sans and Combris 2015). The findings outlined in this paper enhance insight into the sociocultural mechanisms involved in this dietary shift towards more proteinrichanimal based foods in an Indian setting.

The main drivers of this dietary transition according to the predominant narrativebesides prices and agrifood policies - are urbanisation combined with higher revenues, thereby increasing accessibility to these foods. In many cultural contexts, this transition starts with the most affluent and largely urbanised classes (Popkin 1999; Mendez et al. 2004). In line with this trend, Indian society is experiencing unprecedented change, characterised by rapid urbanisation (de Bercegol 2015) and the emergence of a large middle class, ranging from 50 to 300 million (Sridharan 2004). This middle class is striving to distinguish itself by inventing a new class identity with values and lifestyles that veer away from those imposed by their religion or caste, eventually altering their food habits, as noted by the growing consumption of animal products. The Indian National Sample Survey on household expenditures and consumption revealed that, between 1988 and 2010, yearly per capita meat consumption almost doubled in rural areas of India (from 1.3 to $2.5 \mathrm{~kg}$ by 2010), while in urban areas, including towns and cities, it increased by 1.5 fold (from 2.6 to $3.9 \mathrm{~kg}$ by 2010). Yet Indian per capita meat consumption remains very low at $2.9 \mathrm{~kg}$ a year, compared to the world average of $34.1 \mathrm{~kg}$ (Gulati and Varma 2016). During the same period, yearly milk consumption increased by $30 \%$ in rural areas and by $50 \%$ in cities, to reach 50 and 64 1, respectively (NSSO 1997, 2012). The fast-growing Indian middle class is driving the demand for more meat, eggs, fish and dairy products that are generally incorporated in traditional Indian recipes as well as in new 'Western' dishes such as pizzas and burgers, which in turn are symbols of affluence and modernity. The average monthly expenditure for animal products across all classes is higher in urban areas, i.e. Rs 132 vs Rs 81 in rural areas. Interestingly, the expenditure gap between the poorest and richest classes is more marked with respect to dairy products than to meat, eggs and fish, which means that revenue is not the predicator for eating meat, eggs and fish, while the less wealthy classes are spending more on such foods in proportion to their revenues. Similarly, this gap is reported to be Rs 224 for dairy products vs. Rs 60 for meat, eggs and fish (NSSO 2008) in cities, and Rs 149 and Rs 49, respectively, in rural areas. Moreover, substantial state-wise variations have been noted within India (Dorin and Landy 2009) due to its ethnic diversity and sociocultural differences.

This dietary change process from plant- to animal based foods concomitant with economic development served as empirical material for Popkin (1993) when building his nutrition transition model. This model describes a dietary transformation involving an increase in animal based lipids and proteins, followed by stagnation and then a decrease in this intake at the end of the cycle. Dietary shifts that occur during each transition stage 
seem to be an adaptive response to changing nutritional needs dependent on economic environment and lifestyles. Therefore, the model conveys the idea of a 'natural' aspiration towards eating animal proteins, as favoured or limited by income, food supply and physiological needs, ultimately resulting in a substitution of plant-based proteins by animal based proteins. The transition stage in India is unclear according to this linear model. In fact, the diet structure has not reached the stage where animal calories, fats and proteins predominate in diets, whereas the overall calorie intake has reached a saturation level (Deaton and Drèze 2009; Landy 2009). The dietary transition from plant- to animal based proteins is clearly occurring at a slower rate in India than in other countries with similar economic growth rates: over the 1961-2013 period, animal products only increased from 5.5 to $9.7 \%$ in the caloric supply, while animal proteins increased from 11.7 to $20.2 \%$ in the protein supply. In China over the 2011-2013 period, these rates were respectively reported to be 23 and $40.1 \%$ (FAO 2013). Besides, the animal proteins mainly consumed are from foods which do not involve slaughtering animals, e.g. dairy products and eggs, or they are from non-anthropomorphized ${ }^{1}$ animals like chicken or fish. In fact, animal based food consumption is made possible through mechanisms that lead to a discontinuity between the animal and the food status. For example, culinary techniques modify the appearance of the food to be eaten and may disguise any animal origin, while certain linguistic usages create a symbolic distance by avoiding the proper name of the animal or the flesh (Fourat 2018).

\section{Social construction of animal based foods in India}

The geographic, cultural and religious diversity of India is reflected in the generous variety of vegetarian and non-vegetarian cuisines. Nevertheless, lentils and dairy products supply a major share of proteins in the Indian diet, with very few coming from meat and fish - this is because the vegetarian diet is culturally and socially valued in the country. As Alsdorf stated, "Not a majority are vegetarian in India, but the legitimacy of this particular diet has nowhere else in the world any parallel and even non-vegetarians respect the sanctity of the cow." (Alsdorf 2010 [1962]: 2). Hence, the promotion of milk and dairy products, concomitant with the emergence of the taboo on meat-eating, has been largely discussed in literature. Some authors advocate utilitarian explanations, such as the necessary adaptation to climate and geography, or point out the economic interest of making effective use of cow by-products (Harris 1966; Gadgil and Guha 1992). However, this techno-environmental model does not seem relevant for India and it overlooks the underlying religious and sociopolitical forces (Brown 1964; Batra 1986; Doniger 1999; Hoffpauir 1982; Mahias 1988; Korom 2000; Lodrick 1982). During the Vedic period, cattle-meat was relished by the Emperors (Achaya 2009) and all types of meat were incorporated in Ayurvedic pharmacopoeia remedies (Zimmermann 1982). The further devaluation of meats and foods requiring animal slaughter could be explained by the shift in the Brahmin 'food model' as defined by Poulain (2002), ${ }^{2}$ i.e. the group of

\footnotetext{
${ }_{1}$ Animals whose physical attributes and reproduction differ from those of humans.

2 The food model is a sociotechnical and symbolic set that marks the identity of a group and participates in the differentiation process. The food model is circumstantial and not static because it considers food as a dynamic process resulting from biological, environmental, cultural and social interactions. This tool overcomes the aporia of opposing these dimensions, by linking them together and providing a 'free space', for both the societies that face these constraints, and individuals caught in the social structures.
} 
individuals positioned at the top of the social hierarchy who are holders of religious functions. In fact, in the first few centuries BCE, Brahmin priests - influenced by Jainism and Buddhism - started abandoning animal sacrifices and adopting non-violent practices, according to the ahimsa concept (Alsdorf 2010[1962]). Written at the same period, the Law of Manu (a popular and authoritative book of Hindu law), describes foods that are permitted or prohibited according to the person's social rank, along with values and duties inherent in the dharma concept, thereby constituting the hierarchy of individuals and diets. According to those rules, Brahmins perform religious rites and are supposed to be strict vegetarians - they maintain their status by avoiding eating meat, fish and eggs, i.e. essentially what non-Brahmins consume or touch. The other social groups include the Kshatriya caste - traditionally warriors and kings - as well as the Dalits, who are also referred to as 'untouchables' because they are considered impure as eaters of animal flesh-based food. The book offers different layers of understanding of rules related to the prohibition of killing and eating meat, but it has nonetheless formalised the hierarchy between the two vegetarian and non-vegetarian 'models' perpetuated by religious rituals. Whether vegetarian or non-vegetarian, using milk or sacrificing animals, the religious ritual hierarchy follows by analogy that of humans who perform rituals ${ }^{3}$ and that of the Gods of the Pantheon, i.e. vegetarian or non-vegetarian (Malamoud 1989; Ghasarian 2004; Landy 2010). These 'models' are not categories 'imagined' by Western researchers (Inden 1990), but are quite fundamental in eating decisions in India, while also shaping identities (Fourat 2015). The shift towards dietary avoidances and the vegetarian versus non-vegetarian dialectic are rooted in an entangled phenomenon of symbolic and social distinction.

Symbolically, food carries properties from the giver to the receiver and consequently can potentially contaminate. Indeed, sacrifice is symbolised by the gift of food from the hand of a believer who deposits an offering in the mouth of another devotee (Malamoud 1996). Food acceptance thus depends on the ritual status of the donor and the recipient of the food, i.e. according to a rank in the temple (Marriott 1968; Khare 1976; Appadurai 1981) and to the food-the status of a Brahmin is thus maintained by avoiding eating what other groups of people consume or touch, including meat, fish and eggs. Pure and impure food categories in correspondence with social groups are not specific to India since all cultures separate pure and impure foods, whose role is to maintain social order (Douglas 1967), but in India purity is a pivotal ideology as it is enmeshed with a persistent system of social hierarchy. In fact, these food practices are firmly established since they have a primordial function as constituents of the dharma of each caste, while also being a condition for the belief in reincarnation that liberates believers from the cycle of birth and death according to Hindu religious thought (Weber 2003[1958]). Vegetarianism thus became established as a model of 'being in the world' in Indian society, while perpetuating the separation between vegetarian Brahmins and meat-eaters. ${ }^{4}$ Brahmins thus shunned eggs and meat of any kind, setting a standard that ensured that they were the purest beings and hence belonged to the highest caste. The other non-vegetarian 'model' referred to the diet

\footnotetext{
${ }^{3}$ Besides, the butcher function is relegated to the lower castes and Muslims but to priests as in the case of the imam or rabbi.

${ }^{4}$ These mechanisms can be understood in the light of the principle of incorporation described by Claude Fischler (1988). The principle conveys that eating determines the eater's inclusion or exclusion in different social groups since food carries cultural and social values.
} 
of the other social groups having other functions in society, such as the Kshatriyas (warriors) and Dalits.

This hierarchy, however, inspired both rejection and acceptance, as well as movements towards vegetarianism and non-vegetarianism. Some academics have reported that lower castes converted to vegetarianism (Michelutti 2008; Staples 2014) as a means to upgrade their status in society via the Sanskritization process ${ }^{5}$ and the adoption of the Brahmanical practice of purity (Srinivas 1952). Conversely, nonvegetarianism as well has a positive symbolic and social value by contributing to the construction of the identity of other social or religious groups, such as scheduled castes, Muslims or Christians (Ilaiah 1996; Desai 2008; Staples 2008, 2014; Sebastia 2017), for whom meat is a premium dish offered to visitors. An ethnographic study on the Malayali Hindu group in Kerala (Osella and Osella 2008) showcased the process of social distinction through diets: although Brahmins are vegetarian and non-Brahmin Nayars are usually non-vegetarian, during religious festivals they are vegetarian, and the caste of Viswakarma craftsmen positioned just below promotes vegetarianism, contrary to Dalits for whom this practice has no value.

Vegetarianism and non-vegetarianism thus seem to be contextual, even for social groups with strict food prohibitions. Dumont (1967) pointed out that a Bengali Brahmin can eat fish and a Kashmiri can eat meat in circumstances in which there is no need for social distinction. Khare (1966) attributed an 'anomalous' case of Brahmins eating meat to a process of adaptation to modern life. Even more today, eating nonvegetarian dishes occasionally is part of the middle-class ${ }^{6}$ lifestyle (Caplan 2008; Janeja 2010; Staples 2014) in both cities and rural regions (Baviskar 2012), even for Brahmins, thus displaying modernity and emancipation from religious or caste prescriptions. Individuals use different scales of status to interact in diverse social contexts, e.g. places of work or living, and food plays an active role in these interactions (Béteille 2012; Strumpell 2008).

\section{The questions}

It is generally assumed that meat consumption accompanies a social process of distinction of a new middle class imitating the elite, due to the high social status associated with meat dishes (Goody 1982). Since the elite also promulgates vegetarianism in India, and the middle class seems to refer to the elite, the middle class should favour vegetarian diets. A recent article based on national surveys clearly stated that characterising India as a vegetarian land is a misrepresentation of reality since "the vegetarian population of India is at best $31 \%$ and realistically less than $20 \%$ " (Natrajan and Jacob 2018). Whereas newspaper articles regularly discuss whether India is becoming more non-vegetarian or vegetarian (Gulati and Varma 2016; Bansal and

\footnotetext{
${ }^{5}$ Sanskritization, a particular form of social change found in India, denotes the process by which castes placed lower in the caste hierarchy seek upward mobility by emulating the rituals and practices of the upper or dominant castes (Srinivas 1952).

${ }^{6}$ The middle class in India, however, constitutes a heterogeneous group and is often split into sub-economic groups (Sridharan 2004). On that matter, Deshpande (2006) accurately pointed out that popular meanings of middle class in India do not position it in the middle along the class spectrum. Actually, the term refers to the affluent class rather than the middle class by any reasonable definition (occupation, revenue, consumption patterns, lifestyle).
} 
Kishore 2018), they fail to provide a full definition of non-vegetarianism and vegetarianism, what exactly comprises such diets and their consumption frequency. Although socioeconomic and cultural drivers such as income, education and ethnicity, have been acknowledged in dietary transitions, little is known about the way they concretely influence such transitions. We consequently focused on addressing the following questions: How does socioeconomic status combined with religious or caste status impact food practices and consumption? Are Brahmins vegetarian? Do wealthy people eat meat? Is the adoption of vegetarianism for the purpose of rising up the social ladder (Sanskritization) still valid? Does the hierarchy of diets remain the same? What exactly are vegetarian and non-vegetarian diets?

This paper thus focuses on the concrete aspects of consumption and how vegetarianism, or non-vegetarianism, covers different realities (meanings of vegetarian and non-vegetarian foods, place and times of eating) related to values attached to vegetarian and non-vegetarian foods and to sociocultural determinants of consumption (according to status in the society and social contexts of eating). To gain insight into the dietary transition towards animal proteins, we investigated norms and values attached to foods and their interrelations with eating practices according to their spatiotemporal and social dimensions.

\section{Aim and methodology}

The study was carried out in the urban cosmopolitan city of Vadodara in Gujarat state, western India. The aim was to assess animal based consumption patterns specifically with regard to religion, gender, age and socioeconomic status, while also identifying people who consumed more animal based products and determining the extent of integration of non-vegetarian foods in households. It documented people who were more inclined to consuming animal based foods with regard to their values, attitudes and beliefs related to such foods, while identifying the sociocultural factors that influenced their eating decisions. The survey was conducted in summer 2014.

\section{The location}

Gujarat State was selected as the study setting for several reasons. Economically, it is one of the most advanced states of India, notably in the dairy product, meat, poultry and fisheries industries - Gujarat ranks fifth in milk production in India, contributing to about $8 \%$ of India's total milk production (ASSOCHAM 2014). Besides, over the centuries Gujarat has developed a strong vegetarian identity and cuisine. Hinduism constitutes the religion of approximately $89 \%$ of its population. Specific social groups such as the Vaishnav sect, and also the Jains, who account for only about $1 \%$ of the population, also have a noticeable presence in Gujarat as they have developed into a strong class of merchants and traders. Moreover, Mahatma Gandhi who was born and raised in Gujarat reinforced this dietary pattern by advocating the concept of nonviolence and vegetarianism in opposition to the imperialism of Great Britain. The chosen city, Vadodara, is the third largest city in Gujarat and concentrates $85 \%$ of Hindus according to the 2011 census. Its economic and industrial growth has resulted in growing prosperity, especially of the middle class (Census of India 2011). Restaurants 
in Vadodara are largely vegetarian (KFC, Mc Donalds, and Subway make it a point to advertise and sell vegetarian items in addition to non-vegetarian items). In restaurants where meat-based foods are also served, the expected norm is to have separate kitchen spaces. While egg joints always existed in the city, there has been a proliferation of egg handcart joints in recent times, bearing names such as 'Egg Station', 'Fresh Eggs', and 'Mr. Egg'.

\section{The sample}

A stratified equally divided sample of 432 women and men was selected. To ensure a minimal reasonable size for sub-clusters, we constituted three categories of Hindus Brahmins, Hindus non-Brahmins and Jains, since the latter are a dominant group in Gujarat and considered to be more stringent than the Brahmins in their eating habits. The Brahmin/non-Brahmin categories do not reflect the diversity of castes and religions in India, although they represent sociopolitical categories (Pandian 2008). We focused on Hindus since they represent $80 \%$ of the total population, although it would have been interesting to include Muslims, Christians and Buddhists and assess their social capacity to produce taboo food avoidance patterns. Next, depending on the food transition theory which postulates that the rich eat more animal based foods and are often imitated by the poor, the population was selected according to three socioeconomic levels (hereafter denoted SES, for socioeconomic status, since the education and income levels were highly correlated) of 72 individuals in each group: high income group (HIG), medium income group (MIG) and low income group (LIG). The three socioeconomic status (SES) categories were selected on the basis of the type of housing and amenities present in the house. Localities in which participants from each SES were expected to reside were also identified at the time of data collection. Each group was further divided into an age-wise stratification of young, middle and old ( $n=8$ each).

\section{Definition and measurement of variables}

Although individuals tend to under- or over-estimate their food consumption frequency according to norms (Ulijaszek 2004), it was decided in this case to ask about the consumption frequency but not to conduct a 24-h recall because this interval is too short to record occurrence in India. This reflected the different consumption cycles for each food, i.e. daily, weekly, monthly or yearly. The prevalence of animal based food consumption was also measured according to the duration of the introduction of these foods in the domestic sphere (whether recently or since several generations), and how these foods were consumed (cooked in the same or separate utensils used to cook vegetarian foods, or eaten but not cooked at home). The choice of the food items was justified. Paneer (a sort of cottage cheese) was added separately from dairy products, as it was an expensive product, and seen as a source of protein and calcium for vegetarians. Eggs were consumed in two ways, which we defined for this survey as 'recognisable' (omelette, curried eggs, etc.) or 'non-recognisable' (in cookies, creams, pastries, etc.) as this appeared to be a relevant distinction, at least in the Indian context (Table 1). For flesh foods, we represented each category, i.e. poultry, fish, seafood and red meat, but we did not find any answers regarding pork and beef in the sample after pre-tests. Hence, the following diet categories were established: 
Table 1 Diet categories

$\begin{array}{ll}\text { Lacto-veg diet } & \begin{array}{l}\text { Includes only milk and dairy products; excludes all flesh foods, recognisable or even } \\ \text { non-recognisable eggs } \\ \text { Includes milk and dairy products and also recognisable and non-recognisable eggs }\end{array} \\ \begin{array}{l}\text { Ovo-lacto-veg diet } \\ \text { Selected red meat diet }\end{array} & \begin{array}{l}\text { Includes milk and dairy products, eggs, and some selected meats (in the case } \\ \text { of our survey in Vadodara, only mutton/goat meat; with beef and pork being } \\ \text { excluding for religious reasons) }\end{array} \\ \text { Chicken-meat diet } & \begin{array}{l}\text { Includes milk and dairy products, eggs and chicken, but excludes red meat } \\ \text { Includes milk and dairy products, eggs and fish }\end{array} \\ \text { Fish diet } & \end{array}$

\section{The values on food and consumption contexts}

The research questions intended to capture the cultural values of these animal based, vegetarian and non-vegetarian foods. The goal was to outline the 'content' of these categories. Moreover, the choice of food was examined in the social context of the eater, whether alone, with family or with friends, on an ordinary day, a religious holiday, a birthday celebration, etc. The questionnaire contained 29 questions on feeding practices and representations (168 possible answers) and 24 socioeconomic and demographic statuses (55 response categories). The data were analysed descriptively in terms of frequencies and percentages of responses in different categories. Chisquare tests, $t$ tests and ANOVA were conducted to assess differences among the independent variables (SES, gender, religion, age, education and marital status). Multiple regression was applied to determine the relative contribution of the independent variables. In the following paragraphs: $\mathrm{M}=$ mean; $\mathrm{SD}=$ standard deviation; $\mathrm{Chi}^{2}=$ Pearson's chi-square test. Note that many of the questions and suggested modalities of answers were derived from a previous qualitative study of 43 comprehensive interviews conducted in Delhi.

\section{Results}

The results of this study first offer an overall picture of types of diets, occasions and values related to eating vegetarian and non-vegetarian food. We then discuss the reasons for the acceptance or non-acceptance of certain foods in Vadodara households, according to timing and socioeconomic determinants. We follow up by assessing decisions made outside the households regarding the social contexts.

\section{What is 'veg' and 'non-veg' food?}

In categorising milk and dairy products as vegetarian or non-vegetarian, almost all of those surveyed (98\%) said that they are vegetarian products. Milk was not viewed as a 'non-veg' food as it was not associated with harming or killing an animal for consumption purposes. Eggs, on the other hand, were categorised as non-vegetarian by a majority of the participants $(95 \%)$, while only $4 \%$ said that they are vegetarian and $1 \%$ had no opinion. More participants from the low-income group, men and the non- 
Brahmin group believed eggs to be a non-vegetarian food. Table 2 below summarises the items that were included in the different food categories and the specificity we found in India with the separation of eggs into two sub-categories: eggs non-specified and eggs non-fertilised as a symbolic process to mark a distance with respect to the possibility of taking a future life (Fourat 2015, 2018). In our study, according to the participants, a non-vegetarian diet included meat of ruminants, poultry, fish, eggs nonspecified, eggs non-fertilised and dairy products. With regard to animal products, a vegetarian diet only included eggs non-fertilised and dairy products, while a vegan diet did not include any of these.

\section{Values given to vegetarian and non-vegetarian foods}

Most participants (90\%) considered vegetarian food to be tasty and healthy, $88 \%$ felt that it gave strength and $86 \%$ viewed it as pure food. Only $66 \%$ thought that consuming vegetarian food brings good karma. Participants who did not feel that salvation could be achieved by consuming a vegetarian diet were among the non-Brahmin, younger age and unmarried groups. Surprisingly, only about two-fifths of the participants (45\%) agreed that killing animals was not good, while about one-third of them disagreed that plant-based proteins were better than meat and dairy proteins. Regarding the two latter questions, more participants from non-Brahmins and lower education groups thus appeared to lean towards higher disagreement and hence against vegetarian norms as compared to their counterparts, suggesting that they felt that it was alright to kill animals. These groups had the highest acceptance of non-vegetarian food consumption compared to Brahmins, Jains and participants with middle and higher education levels. Non-vegetarian food consumers felt that it was alright to eat meat if their religion allowed animal sacrifice (83\%). Slightly more than half agreed that meat proteins were better than vegetable proteins $(52 \%)$, and less than half agreed that meat proteins were better than dairy proteins $(45 \%)$.

\section{Diet profiles regarding animal based foods}

Table 3 displays participants' diet profiles according to animal products included in/ excluded from their diet (as detailed in Table 1). According to the declared frequency of consumption of each animal product, none of the participants had an 'all meat diet' or were vegan. Moreover, no participants had an exclusive fish diet and those consuming fish and other seafood were categorised in the 'select red meat diet' category as they generally also consumed chicken and/or mutton. Most participants followed a 'lacto-

Table 2 Content of veg and non-veg categories according to the survey

\begin{tabular}{lllllll}
\hline & $\begin{array}{l}\text { Meat of } \\
\text { ruminants }\end{array}$ & Poultry & Fish & $\begin{array}{l}\text { Eggs } \\
\text { non-specified }\end{array}$ & $\begin{array}{l}\text { Eggs } \\
\text { non-fertilised }\end{array}$ & $\begin{array}{l}\text { Dairy } \\
\text { products }\end{array}$ \\
\hline Non-vegetarian diet & Yes & Yes & Yes & Yes & Yes & Yes \\
Vegetarian diet & No & No & No & No & Yes & Yes \\
Vegan diet & No & No & No & No & No & No \\
\hline
\end{tabular}


E. Fourat et al.

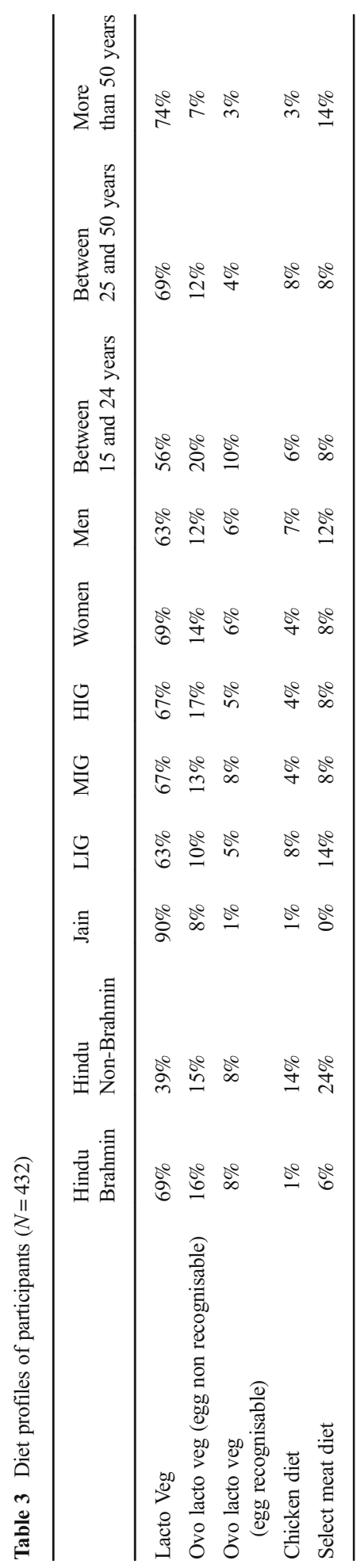


veg' diet. More men (19\%) had a non-vegetarian diet as compared to women (12\%); non-Brahmins and lower income groups had a chicken or 'selected red meat' diet more frequently (38\%) than Brahmins (7\%). An 'Ovo-lacto veg' (non-recognisable or recognisable egg) diet was equally followed by Hindu Brahmins or non-Brahmins, as well as youngsters from medium and high-income groups. A total of $69 \%$ of Brahmins, but only $39 \%$ of non-Brahmins, were pure vegetarians.

\section{Consumption frequency}

Non-vegetarian individuals eat eggs, chicken or red meat several times a year or every day. To combine animal products consumed and frequencies, we determined a typology of diets according to their consumption cycles. We coded the consumption. If an individual never eats eggs, fish, chicken and other meats he/she is a 'permanent vegetarian'. If an individual eats at least one product (among eggs, fish, chicken and other meats) every day, then he/she is a 'non-veg regular'. We have included eggs since they are mainly considered as being a 'non-veg' food. If an individual eats at least one of these same foods at least once a week then he/she is a 'short cycle vegetarian'. If an individual consumes at least two of these foods several times a month then he/she is a 'vegetarian middle cycle'. If an individual consumes at least two of these foods less than once a month, then he/she is a 'vegetarian long cycle'. The most significant variables for temporalities were religion/caste and socioeconomic status. We thus outlined ideal types of diet.

- The 'Permanent Veg' type pooled middle and upper-income individuals (69\%), mostly Brahmins and Jains. They had the same values as 'Lacto-veg' consumers, since they were the same individuals except that we also integrated those who consumed non-recognisable eggs. They were more numerous than pure vegetarians because they included NR eggs.

- The 'Veg long cycle' type corresponded to middle and upper-income individuals (76\%), 60\% women, Brahmins and Hindu non-Brahmins (but no Jains), with high levels of education. These individuals allowed themselves to eat meat a few times a year, on special occasions between friends, or for health reasons, but not by tradition, or during religious holidays, or for budgetary constraint reasons. Their values resembled those of permanent vegetarians and lacto-vegetarians, except with respect to nutritional values because they considered that meat and milk proteins were better-an opinion that was linked with their level of education.

- On the other hand, the 'Veg medium cycle' type was more represented by low income and non-Brahmins with medium levels of education. They included nonBrahmin middle-class men who ate meat more at religious festivals and when they had enough money to purchase meat. They valued both animal and plant proteins. They did not consider meat proteins to be better than milk or vegetable proteins.

- The 'Veg short cycle' type pooled men from the low socioeconomic group, especially non-Brahmins, men. Neither vegetarianism nor non-vegetarianism was really a tradition for them, they readily ate meat on special occasions with friends, or for health reasons. 
- The 'Regular non-veg' type referred to males, between 25 and 50 years old, with a high socioeconomic status (Table 4).

\section{Acceptance of non-vegetarian foods in households vs. the purity principle}

The consumption frequency was highly correlated with the introduction of nonvegetarian food at household and community levels $(r(432)=0.744, p=.000)$ because of the values that families attached to food. In response to the question 'Do you accept "non-veg" food in the home' ( $n=104), 76 \%$ of households excluded 'non-veg' food, $19 \%$ tolerated all, and $5 \%$ of households had only introduced eggs. The household acceptance and exclusion of 'non-veg' food was related to the religion/caste $\left(\mathrm{Chi}^{2}=\right.$ 38.8), SES $\left(\mathrm{Chi}^{2}=16.6\right)$ and education $\left(\mathrm{Chi}^{2}=10.2\right)$. A higher percentage of total acceptance of non-vegetarian foods was thus observed more among the LIG (50\%), non-Brahmins (85\%) and participants with middle-level education (48\%). Traditionally, non-vegetarian food is not allowed in the homes of Brahmins and Jains because poojas are performed or due to the presence of a small temple at home. In only $13 \%$ of households, 'non-veg' foods were eaten at home but uncooked, e.g. they were sometimes ordered or brought back from the market and eaten at home. Once 'non-veg' foods were accepted in households, more than two-thirds of households $(66 \%)$ cooked these foods in the same utensils as they used for vegetarian food, and only a fifth reported

Table 4 Typology of diets according to frequency $(N=432)$

\begin{tabular}{|c|c|c|c|c|c|c|c|c|c|c|}
\hline \multirow[b]{2}{*}{ Women } & \multicolumn{2}{|c|}{$\begin{array}{l}\text { Veg } \\
\text { permanent }\end{array}$} & \multicolumn{2}{|c|}{$\begin{array}{l}\text { Veg long } \\
\text { cycle }\end{array}$} & \multicolumn{2}{|c|}{$\begin{array}{l}\text { Veg medium } \\
\text { cycle }\end{array}$} & \multicolumn{2}{|c|}{$\begin{array}{l}\text { Veg short } \\
\text { cycle }\end{array}$} & \multicolumn{2}{|c|}{$\begin{array}{l}\text { Regular } \\
\text { Non-veg }\end{array}$} \\
\hline & 178 & $52 \%$ & 15 & $60 \%$ & 16 & $35 \%$ & 7 & $37 \%$ & 0 & $0 \%$ \\
\hline Men & 163 & $48 \%$ & 10 & $40 \%$ & 30 & $65 \%$ & 12 & $63 \%$ & 1 & $100 \%$ \\
\hline \multicolumn{11}{|l|}{ Age } \\
\hline 15-24 years & 108 & $32 \%$ & 11 & $44 \%$ & 18 & $39 \%$ & 6 & $32 \%$ & 1 & $100 \%$ \\
\hline $25-50$ years & 117 & $34 \%$ & 6 & $24 \%$ & 15 & $33 \%$ & 6 & $32 \%$ & 0 & $0 \%$ \\
\hline Above 50 years & 116 & $34 \%$ & 8 & $32 \%$ & 13 & $28 \%$ & 7 & $37 \%$ & 0 & $0 \%$ \\
\hline \multicolumn{11}{|l|}{ Education level } \\
\hline Low & 49 & $14 \%$ & 3 & $12 \%$ & 10 & $22 \%$ & 6 & $32 \%$ & 0 & $0 \%$ \\
\hline Medium & 145 & $43 \%$ & 12 & $48 \%$ & 25 & $54 \%$ & 7 & $37 \%$ & 1 & $100 \%$ \\
\hline High & 147 & $43 \%$ & 10 & $40 \%$ & 11 & $24 \%$ & 6 & $32 \%$ & 0 & $0 \%$ \\
\hline \multicolumn{11}{|l|}{ SES } \\
\hline LIG (low incomes) & 106 & $31 \%$ & 6 & $24 \%$ & 19 & $41 \%$ & 13 & $68 \%$ & 0 & $0 \%$ \\
\hline MIG (medium incomes) & 115 & $34 \%$ & 10 & $40 \%$ & 16 & $35 \%$ & 3 & $16 \%$ & 0 & $0 \%$ \\
\hline MIG (high incomes) & 120 & $35 \%$ & 9 & $36 \%$ & 11 & $24 \%$ & 3 & $16 \%$ & 1 & $100 \%$ \\
\hline \multicolumn{11}{|l|}{ Religion/caste } \\
\hline Brahmin & 122 & $36 \%$ & 7 & $28 \%$ & 12 & $26 \%$ & 3 & $16 \%$ & 0 & $0 \%$ \\
\hline Non-Brahmin & 77 & $23 \%$ & 18 & $72 \%$ & 32 & $70 \%$ & 16 & $84 \%$ & 1 & $100 \%$ \\
\hline Jain & 142 & $42 \%$ & 0 & $0 \%$ & 2 & $4 \%$ & 0 & $0 \%$ & 0 & $0 \%$ \\
\hline
\end{tabular}


using separate utensils (21\%). Marie-Claude Mahias (1985, p. 147) had demonstrated that the purity of kitchen utensils in Jain households ensures religious and social purity.

\section{Eating contexts: vegetarian food is a staple and a social norm}

For most of the participants (70\%), vegetarian food represented their staple diet, in line with their traditions, and this diet was also respected during religious festivals. Middleincome group participants $(\mathrm{M}=1.88, \mathrm{SD}=0.993)$ and the Jains $(\mathrm{M}=1.90, \mathrm{SD}=0.999)$ had significantly higher scores compared to their counterparts with regard to consuming vegetarian foods during religious fasting festivals. Almost two-thirds (62\%) disagreed that they ate vegetarian to abstain from meat. More men and non-Brahmins with little or no education had higher levels of disagreement towards abstaining from meat. However, this was not because they abstained from non-vegetarian food but rather because vegetarian food was their staple diet. Eating vegetarian was not a question of affordability since $97 \%$ disagreed with eating vegetarian food because of economic restrictions.

Conversely, non-vegetarian food was less relevant when celebrating religious festivals $(30 \%)$ and more prevalent during convivial occasions with family or friends $(54 \%)$. For $20 \%$ of the participants, mainly from the low-income group, nonvegetarian food was eaten when they had enough money. A little more than half the participants $(52 \%)$ reported that they 'never' ate out or did so less than once a month, while $39 \%$ ate out once or twice a month. The high-income group participants had significantly higher scores $(\mathrm{M}=1.83, \mathrm{SD}=0.693)$ than the other two groups, indicating that they ate out more often than the other groups. While gender and religious differences were not significant, men and non-Brahmin participants scored higher, showing that they ate out more frequently. Significantly higher scores were noted among younger participants $(M=1.81, S D=0.669)$, the unmarried group $(M=3.22$, $\mathrm{SD}=1.142)$ and participants with higher levels of education $(\mathrm{M}=1.80, \mathrm{SD}=0.677)$, indicating that they ate out more often than their counterparts.

In response to the question 'You eat non-veg/eggs, but your friends are vegetarian, what type of food would you order in a restaurant?', most people $(68 \%)$ said they chose a vegetarian dish. In response to the question 'What do you eat at restaurants during fasting festivals with family or friends?', an overwhelming majority (99\%) of people said that they chose vegetarian food. The participants were also asked about their food choices when they were invited to a wedding where non-vegetarian food was served. About $18 \%$ of the respondents stated that they would not go at such a wedding, $32 \%$ reported that they would not eat, but participants showed a higher rate of nonvegetarian choices at such occasions since only $38 \%$ would choose only vegetarian food, with slightly more flexibility in consuming non-vegetarian foods when they were accompanied by friends instead of family. These results confirmed that vegetarianism is still the norm in social contexts, and eating non-vegetarian food is easier in a social context where most people are eating non-vegetarian food.

\section{Conclusions}

In this study, we assessed norms and values attached to foods and their interrelations with eating practices according to spatiotemporal and social dimensions in order to gain 
insight into dietary transitions towards animal based foods (as a source of protein). First, the specificities of Indian eating patterns led us to redefine diet profiles by adding a distinction between 'non-recognisable egg' or 'recognisable egg' to the 'Ovo-lacto veg' category, while also adding a frequency variable by differentiating permanent vegetarians from long-cycle vegetarians and from short-cycle vegetarians. We therefore attempted to define the meanings of vegetarian and non-vegetarian foods in the Indian setting, and to profile those who consumed specific animal based foods according to symbolic and social drivers in private or public contexts. The findings revealed that values and norms associated with food at the household level and the social context were key determinants with regard to animal based food consumption. They influenced the acceptance of such foods inside and outside the household, in relation to caste, socioeconomic status and gender. For most of the participants, being vegetarian was a tradition often associated with religion, while non-vegetarian food was only occasionally eaten. In the Vadodara setting, there was hardly any acceptance of meat in middleclass households (irrespective of caste) because the values attached to non-vegetarian food were largely negative and reflected impurity. Non-vegetarian food was mainly accepted in non-Brahmin households with low income and educational levels because meat-eating was not a taboo for them. Acceptance of non-vegetarian foods within the household could involve partial acceptance, i.e. non-vegetarian foods could not be cooked at home but instead bought from outside and eaten at home (preferably in separate utensils). Nevertheless, a recent phenomenon was observed among educated Brahmins of high and medium income groups who tended to introduce non-veg foods and eggs in their diet at home, while the Jains predominantly excluded egg consumption. Egg represents a 'safe' food as it does not involve death of the animal when egg boxes sold in the market are labelled as 'unfertilized'. Non-Brahmins, for whom vegetarian food was normally acceptable, were also inclined to follow a more vegetarian way of life, which emerged from the need to rise in the social hierarchy. This is indicative of the process of imitating the elite higher caste group, which is referred to as the Sanskritization process in India. Outside the house, respect for one's family tradition of consuming only vegetarian food made many participants avoid nonvegetarian food in the presence of family members. In the company of friends or colleagues however, their flexibility or openness increased to the extent of accepting non-vegetarian food or going to eating-places where such foods were on the menu.

Despite the overall increase in animal based food consumption (NSSO 1997, 2012) at individual and household levels, according to our case study in Vadodara, vegetarianism continues to be dominant, as also confirmed by a recent article (Natrajan and Jacob 2018). The increasing share of animal proteins in diets is characterised by a socalled de-animalisation mechanism, as pointed out in our recent co-written article (Fourat and Lepiller 2017). In this latter study, we did not argue in favour of an evolution towards a vegetarian society, but rather we highlighted a decline in the inclusion of animal products in diets, particularly with regard to meats, which symbolically have a strong animal character. That symbolic decline often goes hand in hand, in practice, with a drop in consumption. Nevertheless, in India this encourages consumption of foods of animal origin that are masked by specific culinary transformations, resulting from symbolic de-animalisation mechanisms (Fourat 2018). The vegetarian vs. non-vegetarian rhetoric encompasses the norms and values of eating and being in the world. This situation is amplified in India where there is an ideology of purity and a 
social desirability for being vegetarian. Vegetarianism or non-vegetarianism is contextual since many individuals switch to a vegetarian diet whenever there is a religious festival. It may be appropriate to eat non-vegetarian food in a certain situation but not in another. The findings of our study cannot be generalised due to the wide range of food habits in India that vary across different dimensions regarding location, region/state, social group, within social group, classes, and gender. The primary aim of our study was to understand mechanisms involved in dietary choices, which shape dietary transitions. The findings demonstrated that the validity of a theory or a model depends on the observation scale. In fact, the linear model of nutrition transition driven by a 'natural' ambition to eat animal proteins, favoured or limited by income, food supply and physiological needs, may appear relevant at the macro-scale of nutrient categories, but requires a nuanced culture-specific analysis to reveal the variety of animal based food preferences or avoidances. The Indian case suggests that change is not unidirectional towards the Western model, but each culture has its own unique eating patterns that are deeply embedded in the sociocultural context. Macro-level socioeconomic transformations indeed impact eating patterns, but they interact in complex ways with cultural beliefs and values, thereby eliciting models that reflect distinct culture-specific adaptations.

Acknowledgments We were able to conduct this study thanks to the CIRAD's research fellowship program during Estelle Fourat's PhD thesis. This research was supported by French National Research Agency ("Investment for the Future Program" ANR-10-LABX-0001-01) through Agropolis Fondation Labex Agro under the reference ID 1300-011 and by Danone Research. We also thank the reviewers whose criticisms helped us to considerably improve our argument. Thank you also to David Manley for proofreading. A special thank you to the field investigators who persisted in conducting the survey through various difficult situations (floods, strikes, etc.): Hetal Chavda, Jemima Chauhan, Trupti Desai, Priyanka Patel, Surekha Rathwa, and Divya Vasava. We also thank the research and office staff of the Women's Studies Research Center who pitched in at different stages of the study: Falguni Helaiya, Krupali Patel, Sushma Parekh, Priya Parikh, Khushbu Suthar. Last, but certainly not the least, we owe a debt of gratitude to all the participants who offered their time to respond to the interviews.

\section{References}

Achaya, K. T. (2009). The illustrated foods of India A-Z. New Delhi: Oxford University Press.

Alsdorf, L. (2010[1962]). The history of vegetarianism and cow-veneration in India. Oxford: Routledge, Taylor \& Francis Group.

Appadurai, A. (1981). Gastro-politics in Hindu South Asia. American Ethnologist, 8(3), 494-511.

ASSOCHAM. (2014). Gujarat records highest share in total dairy output across India: study. The Associated Chambers of Commerce and Industry of India. Resource document. http://assocham.org/newsdetail. php?id=4485. Accessed $20 \mathrm{Feb} 2017$.

Bansal, S., Kishore, R. (2018). From meat and fish to vegetables: these 9 charts show how India eats. Resource document. https://www.hindustantimes.com/india-news/from-meat-and-fish-to-vegetables-these-9-chartsreveal-how-india-eats/story-TuuBXEWSUh8rasldtnongP.html Accessed 20th April 2018.

Batra, S. M. (1986). The sacredness of the cow in India. Social Compass, 33(2-3), 163-175.

Baviskar, A. (2012). Food and agriculture. In V. Dalmia \& R. Sadana (Eds.), The Cambridge companion to modern Indian culture (pp. 36-49). Cambridge: Cambridge University Press.

Béteille, A. (2012). The peculiar tenacity of caste. Economic and Political Weekly, 47(13), 41-48.

Brown, W. N. (1964). The sanctity of cow. Economic and Political Weekly, 245-256.

Caplan, P. (2008). Crossing the veg/non-veg divide: commensality and sociality among the middle classes in Madras/Chennai. South Asian Studies, 31(1), 118-142. 
Census of India. (2011). Government of India, Ministry of Home Affairs. Resource document. http://www. census2011.co.in/census/city/338-vadodara.html. Accessed 20th April 2018.

de Bercegol, R. (2015). Petites villes et décentralisation en Inde. Rennes: Presses Universitaires de Rennes.

Deaton, A. S., \& Drèze, J. (2009). Food and nutrition in India: facts and interpretations. Economic and Political Weekly, 44(7), 42-65.

Desai, A. (2008). Subaltern vegetarianism: witchcraft, embodiment and sociality in Central India. South Asia: Journal of South Asian Studies, 31(1), 96-117.

Deshpande, S. (2006). Mapping the "middle": issues in the analysis of the "non-poor" classes in India. In M. E. John (Ed.), Contested transformations: changing economies and identities in contemporary India (pp. 215-236). New Delhi: Tulika.

Doniger, W. (1999). Eating karma in classical South Asian texts. Social Research, 66(1), 151-165.

Dorin, B., \& Landy, F. (2009). Agriculture \& food in India: A half-century review from independence to globalization. Delhi: CSH-Manohar Editions Quae.

Douglas, M. (1967). Purity and danger. London: Routledge \& Kegan Paul Ltd.

Dumont, L. (1967). Homo hierarchicus essai sur le système des castes. Bibliothèque des sciences humaines. Paris: Gallimard.

Esnouf, C., Russel, M., \& Bricas, N. (2011). Pour une alimentation durable: Reflexion stratégique duALIne. Versailles: Quae éditions.

FAO. (2013). Food supply, livestock and fish primary equivalent. Resource document. http://faostat.fao. org/site/291/default.aspx. Accessed 31th Aug 2013.

Fischler, C. (1988). Food, self and identity. Social Science Information, 27(2), 275-292.

Fourat, E. (2015). Socio-anthropologie d'une transition protéique : comprendre la consommation des aliments protéiques d'origine animale à Delhi et Vadodara (Inde). Thèse de doctorat de sociologie sous la direction de J-P Poulain et Bricas N. Toulouse: Toulouse II Jean-Jaurès.

Fourat, E. (2018). The making of edible animal source foods and its contemporary reality in Delhi. In K. Bhushi (Ed.), Farm to fingers: the culture and politics of food in contemporary India (pp. 37-57). New Delhi: Cambridge University Press.

Fourat, E., \& Lepiller, O. (2017). Forms of food transitions: sociocultural factors limiting the diets' animalisation in France and India. Sociologia Ruralis, 57(1), 41-63.

Gadgil, M., \& Guha, R. (1992). This fissured land: An ecological history of India. Oxford: Oxford University Press.

Ghasarian, C. (2004). Représentations et pratiques culturelles alimentaires chez les Tamouls de l'île de la Réunion. In G. Fontaine \& J.-P. Poulain (Eds.), Tourisme dans les départements et territoires d'OutreMer, Patrimoine - Culture Produits et territoires, Actes du Colloque de l'île de La Réunion, (32) (pp. 141147). Paris: Delagrave Editions.

Goody, J. (1982). Cooking, cuisine and class: a study in comparative sociology. London, New York, Melbourne: Cambridge University Press.

Gulati, A., Varma, S. (2016). From plate to plough: a clear trend towards non-vegetarianism in India. Resource document. http://indianexpress.com/article/opinion/columns/india-diet-indian-palate-non-vegetarianvegetarianism-3099363/. Accessed 20th April 2018.

Harris, M. (1966). The cultural ecology of India's sacred cattle. Current Anthropology, 7(1), 51-66.

Hoffpauir, R. (1982). The water buffalo: India's other bovine. Anthropos, 77(1/2), 215-238.

Ilaiah, K. (1996). Beef, BJP and food rights of people. Economic and Political Weekly, 31(24), 1444-1445.

Inden, R. B. (1990). Imagining India. Oxford: Blackwell Publishers.

Janeja, M. K. (2010). Transactions in taste: the collaborative lives of everyday Bengali food. Delhi: Routledge India.

Khare, R. S. (1966). A case of anomalous values in Indian civilization: meat-eating among the Kanya-Kubja Brahmans of Katyayan Gotra. The Journal of Asian Studies, 25(2), 229-240.

Khare, R. S. (1976). The Hindu heart and home. New Delhi: Vikas Publishing House.

Korom, F. J. (2000). Holy cow! The apotheosis of zebu, or why the cow is sacred in Hinduism. Asian Folklore Studies, 59(2), 181-203.

Landy, F. (2009). India, "cultural density" and the model of food transition. Economic and Political Weekly, 44(20), 59-61.

Landy, F. (2010). Dictionnaire de l'Inde contemporaine. Paris: Armand Colin.

Lodrick, D. O. (1982). Man and mongoose in Indian culture. Anthropos, 77(1/2), 191-214.

Mahias, M.-C. (1985). Délivrance et convivialité: le système culinaire des Jaina. Charenton-le-Pont: Éditions de la Maison des Sciences de l'Homme.

Mahias, M.-C. (1988). Milk and its transmutations in Indian society. Food and Foodways, 2(1), 265-288.

Malamoud, C. (1989). Cuire le monde rite et pensée dans l'Inde ancienne. Paris: La Découverte. 
Malamoud, C. (1996). Alimentation, pureté et pollution dans l'Inde Ancienne. Pensée magique et alimentation aujourd'hui, 5, 32-35. Les cahiers de l'OCHA. Paris: OCHA.

Marriott, M. K. (1968). Caste ranking and food transactions: a matrix analysis. In M. Singer \& B. S. Cohn (Eds.), Structure and change in Indian society (pp. 133-172). Chicago: Aldine.

Mendez, M., Du, S. F., Popkin, B. M. (2004). Urbanization, income and the nutrition transition in China: a case study. FAO food and nutrition papers: Globalization of food systems in developing countries: impact on food security and nutrition. $83,169-194$.

Michelutti, L. (2008). We are Kshatriyas but we behave like Vaishyas': diet and muscular politics among a community of Yadavs in North India'. South Asian Studies, 31(1), 118-142.

Natrajan, B., \& Jacob, S. (2018). 'Provincialising' vegetarianism, putting Indian food habits in their place. Economic and Political Weekly, 53(9), 54-64.

NSSO. (1997). Household consumer expenditure in India, NSS 50th Round, 1993-1994. Report No. 404. National Sample Survey Organization.

NSSO. (2008). Household consumer expenditure in India, NSS 63th Round, 2006-2007. Report No. 527 (63/ 1.0/1). National Sample Survey Organization.

NSSO. (2012). Household consumer expenditure in India, NSS 66th Round, 2009-2010. Report No. 541 (63/ 1.0/1). National Sample Survey Organization.

Osella, F., \& Osella, C. (2008). Food, memory, community: Kerala as both 'Indian Ocean' zone and as agricultural homeland. Contributions to Indian Sociology, 31(1), 170-198.

Pandian, M. S. S. (2008). Brahmin and non-Brahmin: genealogies of the Tamil political present. Hyderabad: Orient Blackswan.

Popkin, B. M. (1993). Nutritional patterns and transitions. Population and Development Review, 19(1), 138157.

Popkin, B. M. (1999). Urbanization, lifestyle changes and the nutrition transition. World Development, 27(11), $1905-1916$.

Poulain, J.-P. (2002). Sociologies de l'alimentation: les mangeurs et l'espace social alimentaire. In Sciences sociales et sociétés. Paris: PUF Quadriges.

Sans, P., \& Combris, P. (2015). World meat consumption patterns: an overview of the last fifty years (19612011). Meat Sciences, 109, 106-111.

Sebastia, B. (2017). Beef is our secret of life: controversial consumption of beef in Andhra Pradesh, India. In: Eating Traditional Food: Politics, identity and Practices. Routledge Studies in Food, Society and the Environment. Routledge.

Sridharan, E. (2004). The growth and sectoral composition of India's middle class: Its impact on the politics of economic liberalization. India Review, 3(4), 405-428.

Srinivas, M. N. (1952). Religion and society amongst the Coorgs of South India. London, Oxford: Oxford University Press, The Clarendon Press.

Staples, J. (2008). Go on, just try some!: meat and meaning-making among south Indian Christians. South Asia: Journal of South Asian Studies, 31(1), 36-55.

Staples, J. (2014). Civilizing tastes: from caste to class in south indian foodways. In J. A. Klein \& A. Murcott (Eds.), Food consumption in global perspective: Essays in the anthropology of food in honour of Jack goody (pp. 65-86). Basingstoke: Palgrave Macmillan.

Steinfeld, H., Gerber, P., Wassenaar, T., Castel, V., Rosales, M., \& de Haan, C. (2006). Livestock's long shadow. Environmental issues and options. Rome: FAO.

Strumpell, C. (2008). "We work together, we eat together": Conviviality and modernity in a company settlement in south Orissa. Contributions to Indian. Sociology, 42(3), 351-381.

Ulijaszek, S. J. (2004). Dietary intake methods in the anthropology of food and nutrition. In H. M. Macbeth \& J. MacClancy (Eds.), Researching food habits: methods and problems (pp. 119-133). Oxford: Berghahn Books.

Weber, M. (2003[1958]). Hindouisme et bouddhisme. Paris: Champs, Flammarion.

Zimmermann, F. (1982). La jungle et le fumet des viandes : Un thème écologique dans la médecine hindoue. Paris: Seuil. 